INTERNATIONAL JOURNAL OF MULTidisciplinARY RESEARCH AND ANALYSis

ISSN(print): 2643-9840, ISSN(online): 2643-9875

Volume 04 Issue 12 December 2021

DOI: 10.47191/ijmra/v4-i12-16, Impact Factor: 6.072

Page No.- $1886-1890$

\title{
Factors Affecting the Consumption of Eco-Fashion Products of Vietnamese Consumers
}

\author{
Nguyen Thi Mo ${ }^{1}$, Hoang Van Hue ${ }^{2}$ \\ ${ }^{1,2}$ Hung Yen University of Technology and Education
}

\begin{abstract}
Consumers' awareness of behaviors affecting the environment is increasing, and many people choose to use ecofashion products. Based on the theoretical framework of fashion acceptance, developed by Sproles (1979) combined with empirical research, the author has built a theoretical framework with four shopping-oriented factors; fashion-oriented elements, environmental concerns, and environment-friendly behaviors. From the results of a survey of 450 Vietnamese consumers, all four factors positively influence the consumption behavior of eco-fashion products of Vietnamese consumers. The factor that has the strongest impact on consumer behavior of eco-fashion products is the fashion-oriented factor.
\end{abstract}

KEYWORDS: Consumer Behavior, Fashion, Ecology, Vietnam

\section{INTRODUCTION}

Fashion offers an exciting lifestyle for fashion-conscious consumers but comes at an ever-increasing environmental and social cost. Due to the ill effects of today's fashion consumer behavior, there is growing interest in sustainability issues regarding fashion consumption in the supply chain (Fineman, 2001; Jackson, 2004; Carter et al. Rogers, 2008). Consumers' awareness of their environmental impact is increasing and green products are increasingly available in the market. Along with the economy's growth, people's awareness of greener consumption related to the quality of life of individuals and communities is increasingly improved. The concept of green consumption refers to the use of services and products that meet basic needs and provide a better quality of life without compromising the needs of future generations, i.e., minimizing the use of natural resources and hazardous substances as well as the age of waste and pollutants. According to Gardyn (2003), it is suggested that $70 \%$ of consumers are more likely to buy products from companies that have an environmentally friendly strategy. Many countries have established ecologically friendly development, production, and supply policies to meet the global market demand.

Eco-fashion is a fashion trend that is becoming popular with fashion lovers in Vietnam and worldwide, especially those who love eco-friendly materials. This is a fashion line where all kinds of clothes, fabrics, and accessories are made from natural materials and handmade methods. With eco-friendly characteristics, eco-fashion will direct users to a more sustainable lifestyle. The attitude-behavior gap in environmental protection concerns of fashion and eco-fashion consumers disappoints fashion companies (Weller, 2008) and promotes green marketing. and eco-fashion consumption study to investigate the factors influencing consumers' decision to consume eco-fashion. This study contributes to the assessment of consumers' buying behavior of ecofashion products in the Vietnamese market.

\section{THEORETICAL BASIS AND RESEARCH MODEL}

\subsection{Eco-fashion}

Eco-products are products that are less harmful to humans and the environment.

Reduce waste, benefit society and make the planet a good place to live (Chouhan, Kumar Sharma \& Ameta, 2013). In this sense, ecological products are associated with different terms such as green, ethical, natural, organic, and sustainable products. Many fashion companies, including manufacturers and retailers, are developing and marketing eco-fashion to promote consumption. Accordingly, the terms ethical fashion, eco fashion, and sustainable fashion have become ubiquitous in the media over the past few years (Bennie, Gazibara, \& Murray, 2010).

Eco-fashion is defined as clothing that is designed and produced to maximize benefits for people and society while minimizing adverse impacts on the environment (Joergens, 2006; Claudio, 2007; Ochoa). , 2011). When producing eco-fashion, investors 


\section{Factors Affecting the Consumption of Eco-Fashion Products of Vietnamese Consumers}

consider its effect on the atmosphere created by environmentally friendly products of natural origin and ecologically responsible production processes ( Joergens, 2006; Fletcher, 2008).

Eco-fashion is a brand extension strategy that the fashion industry uses to minimize environmental and social problems, enhance social reputation, and maintain high profits (Choi, Liu, Tang, \& Yu, 2011)

Eco-fashion is a growing design philosophy, and it includes fashion clothing designed to reduce social and environmental impacts, from the growth of the fiber to its use and disposal.

Consumers' fashion interests and needs can be met by the range of products and services offered by manufacturers, wholesalers, and retailers. The variety of the fashions provided by retailers provides enough specific styles to satisfy the need for differentiation and satisfy consumers' preferences for fashion (Gabrielli, Baghi, \& Codeluppi), two thousand and thirteen).

\subsection{Theory of green consumer behavior}

Consumer behavior is the interaction between environmental stimuli and human perception and behavior through which people change their lives. In other words, consumer behavior includes the thoughts and feelings people have and the actions they take in the process of consumption.

Consumers display consumer behavior in finding, purchasing, using, and evaluating products and services that they expect will satisfy their individual needs (Peter D. Bennet, 1988).

"Green consumption" - "green purchasing" (also known as "eco-purchasing") is a term used to refer to the purchase of environmentally friendly products and services. It is the consideration and consideration of environmental issues at the same time as considering and considering the criteria of price and use efficiency when making purchasing decisions to minimize the impact on health and the environment. This consideration can target one or all adverse environmental impacts over their entire life cycle (including production, transportation, use and recycling or disposal) (Le Hoang Lan, 2007). .

Green consumption is called by many different names such as responsible purchasing, ecological consumption, sustainable consumption. It adds environmental considerations with the price and performance criteria of the public and private procurement to purchasing decisions.

It is important to understand that green consumption is not about "consumption less" but about consuming more efficiently, better and using less resources. This is especially true for people living in poverty who often have an increased need to consume products and services. Green consumption is directly linked to many other development priorities such as poverty reduction, economic growth, education and environmental protection. All to improve the quality of life. Therefore, green consumption is not about how to consume less, but how to meet consumer needs in a smarter way.

Green consumption is currently considered the consumption trend of the century when the environment becomes a major concern of many countries around the world. During the past decade, efforts have been made to implement policies and programs to transform the industrial structure successfully, making production processes cleaner and more efficient. However, businesses can only reduce the environmental impacts associated with production, but not address the environmental impacts related to people's selection, use, and disposal of products. Consumption. Therefore, consumption plays an increasingly important role in solving environmental problems; Collaboration between producers, consumers and other stakeholders can lead to more sustainable solutions in the production-consumption system. In that context, integrating the efforts of stakeholders is a key issue to promote green consumption in the world in general and in Vietnam in particular.

\subsection{Fashion acceptance theory}

The theory of fashion acceptance was developed by Sproles (1979), to identify fashion-oriented human behavior and propose variables that influence consumer decision-making regarding the purchase of clothes. The fashion acceptance process described in fashion acceptance theory contains three main variables: the conditions that exist, which directly affect the consumer's choice and use of fashion; consumer decision-making center.

Pre-existing conditions are defined as the consumer's perception and current level of product condition, affecting the consumer's information search. The factors constituting this variable include demographic characteristics (age, gender) and shopping motivation; The factors that directly influence the decision about fashion include social and psychological forces, the inputs to the decision, lifestyle and socio-cultural developments, and the fashion marketing system. Page. Besides, the purchase decision is made by the consumer's purchase decision after the consumer is aware and interested in the product.

In fashion acceptance theory, fashion leaders are more interested in spending more money on fashion products, seeking more fashion-related information, and trying newer fashion products than other items.

Shopping oriented factors

Shopping orientation is used a lot in different studies, explaining individual attitudes towards fashion products on product variety, purchase frequency, and product buying motivation. (Belleau et al, 2001). Fashion leaders are very interested in fashion and they 


\section{Factors Affecting the Consumption of Eco-Fashion Products of Vietnamese Consumers}

show their class in the consumption of fashion products, setting themselves apart from other leaders (Beaudoi et al, 2000). Fashion shopping orientation is an effective factor in describing consumer groups' needs and preferences (Moy and Kincade, 2003). Consumers with different shopping orientations have different preferences, motivations, and buying characteristics. Gutman and Mills (1982) proposed four factors related to fashion orientation: fashion leadership, fashion preferences; the importance of dressing well, and being anti-fashionable.

Concern for the environment

The factor that makes consumers buy eco-fashion products is that they care about the environment and fulfill their social responsibility to protect the environment, buy a lot of green products (Zimmer et al., 2010). 1994). Many consumers of fashion products have perceived the positive concern between environmental issues and green consumption. Bohlen et al. (1993) developed three knowledge indicators on environmental issues; environmental attitudes and environmentally sensitive behaviors to measure ecological concerns.

\subsection{Research model}

\section{Research models}

On the basis of inheriting previous studies combined with practical research, the author proposes the following research model:

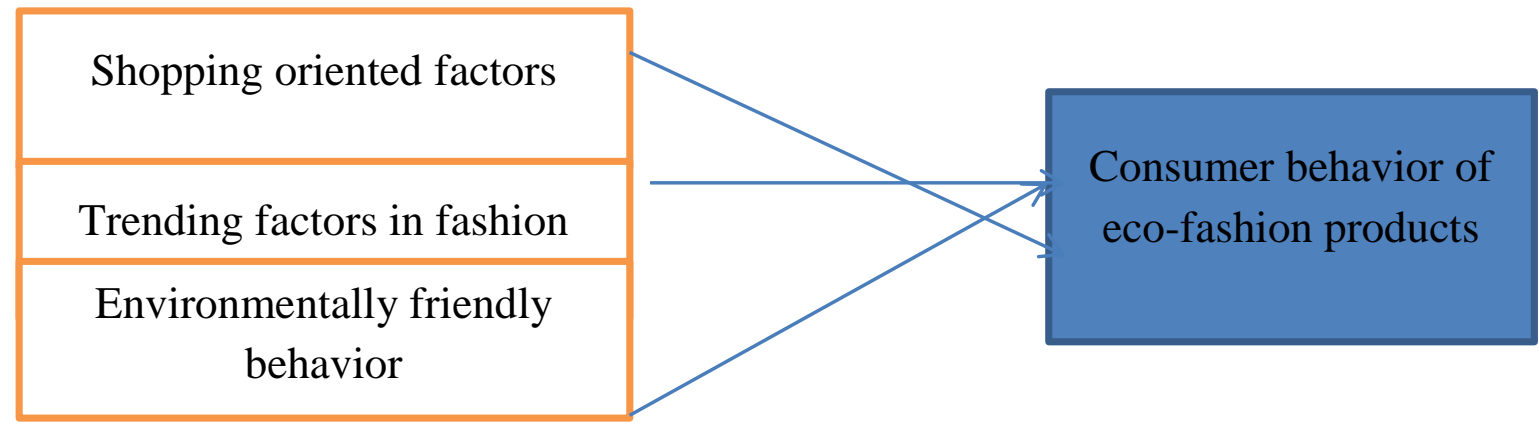

Table 1. Scale of observed variables

\begin{tabular}{|c|c|c|c|}
\hline TT & Variable name & Symbol & Observe \\
\hline \multirow[t]{3}{*}{1} & \multirow{3}{*}{$\begin{array}{l}\text { Shopping } \\
\text { oriented factors }\end{array}$} & SO1 & Enjoy shopping for fashion \\
\hline & & $\mathrm{SO} 2$ & $\begin{array}{l}\text { Consciousness about the cost of shopping for fashion } \\
\text { products }\end{array}$ \\
\hline & & SO3 & Traditional thinking \\
\hline \multirow[t]{4}{*}{2} & \multirow{4}{*}{$\begin{array}{l}\text { Trending factors } \\
\text { in fashion }\end{array}$} & FO1 & Leading fashion \\
\hline & & FO2 & Fashion hobby \\
\hline & & FO3 & The importance of dressing well \\
\hline & & FO4 & Anti-fashion attitude \\
\hline \multirow[t]{3}{*}{3} & \multirow{3}{*}{$\begin{array}{l}\text { Environmentally } \\
\text { friendly } \\
\text { behavior }\end{array}$} & EB1 & Environmental concerns \\
\hline & & EB1 & Environmentally friendly behaviors \\
\hline & & EB1 & Caring about the environment for garment production \\
\hline \multirow[t]{4}{*}{4} & \multirow{4}{*}{$\begin{array}{l}\text { Consumer } \\
\text { behavior of eco- } \\
\text { fashion } \\
\text { products }\end{array}$} & CB1 & $\begin{array}{l}\text { I will buy eco-friendly clothes to help develop organic } \\
\text { farming }\end{array}$ \\
\hline & & CB2 & $\begin{array}{l}\text { Believe in the efforts of enterprises when producing } \\
\text { environmentally friendly products }\end{array}$ \\
\hline & & CB3 & $\begin{array}{l}\text { When I practice sustainable consumption behaviors, I feel a } \\
\text { lot of meaning }\end{array}$ \\
\hline & & CB4 & Concerned about the impact of pants production \\
\hline
\end{tabular}

\section{RESEARCH METHODS}

Qualitative research was conducted through interviewing 20 people including fashion-savvy professionals and consumers of diverse ages and occupations. This research phase was carried out to adjust the scale to suit the scope and research object Quantitative research was carried out by distributing offline survey questionnaires directly to accessible subjects and online questionnaires (google form) to community groups through the social network facebook. 


\section{Factors Affecting the Consumption of Eco-Fashion Products of Vietnamese Consumers}

The survey period was implemented from April 1, 2021 to June 15, 2021. There were 470 survey questionnaires distributed, 462 votes were collected, and 450 valid votes were included in the analysis.

\section{RESEARCH RESULTS AND DISCUSSION}

The results of the first factor analysis showed that most of the factors met the requirements of Cronbach's Alpha coefficient and the variable-total correlation coefficient greater than 0.3 .

EFA exploratory factor analysis was performed with Principal Component Analysis method with Varimax rotation. The independent variable factor analysis results show that the KMO coefficient satisfies the conditions in the factor analysis with the $\mathrm{KMO}$ result of $0.816>0.5$ and the Barletts test with a significance level of 0 (sig $=0.000<0$, sig $=0.000<0$. 05 ) meets the requirements, showing that the observed variables have cohesion, suitable for factor analysis.

Table 2. Factor groups

\begin{tabular}{|l|l|l|l|}
\hline TT & Symbol & Factor name & Observed variables \\
\hline first & SO & Shopping oriented factors & SO1, SO2, SO3 \\
\hline 2 & FO & Trending factors in fashion & FO1, FO2, FO3 \\
\hline 3 & EB & Environmentally friendly behavior & EB1, EB2, EB3 \\
\hline
\end{tabular}

(Source: Author's data processing)

The KMO coefficient of the dependent variable factor analysis met the standard with a value of $0.870>0.5$. Sig coefficient is 0.000 $<0.5$, so the test is significant. The results also show that the observed variable has a component extracted at Eigenvalue of 3.197 $>1.0$; total variance extracted is $55.178 \%>50 \%$.

The results of Pearson correlation analysis show that the factors in the model all have a fairly close linear relationship to the consumer behavior of eco-fashion products. The regression results show the Sig values. The t-test of all factors is less than 0.05 , so no factors are removed.

Table 3. Results of regression analysis

\begin{tabular}{|c|c|c|c|c|c|c|c|c|}
\hline \multirow[t]{2}{*}{ Model } & & \multicolumn{2}{|c|}{$\begin{array}{l}\text { Unstandazized } \\
\text { Coefficients }\end{array}$} & \multirow{2}{*}{\begin{tabular}{|l|}
$\begin{array}{c}\text { Standardized } \\
\text { Coefficients }\end{array}$ \\
Beta
\end{tabular}} & & \multirow[t]{2}{*}{ t Sig. } & \multicolumn{2}{|l|}{ Collinea } \\
\hline & & $\boldsymbol{\beta}$ & Std. Error & & & & Tolerance & VIF \\
\hline \multirow{4}{*}{ S1 } & Const. & 0.463 & .150 & & 1.223 & .000 & & \\
\hline & SO & .289 & .175 & .158 & .289 & .043 & .042 & 1,966 \\
\hline & FO & 342 & .268 & .351 & 1.291 & .000 & .045 & 1.409 \\
\hline & EB & .257 & .092 & .214 & 5.672 & .000 & .247 & 1.887 \\
\hline & \multicolumn{3}{|c|}{ Adjusted R Square $=0.618$} & $F=145.78$ & \multicolumn{4}{|c|}{ Sig $=0.000$} \\
\hline
\end{tabular}

a. Dependent Variable: $\mathrm{CB}$

Source: Author synthesized and processed on SPSS

From Table 3, it can be seen that $F=145.78$ with $\mathrm{Sig}=0.000$ is considered significant for the population; VIF ranges from 1,409 to 1,966 are all less than 2.0, the Tolerance coefficient is low, so there is no sign of multicollinearity and there is no strong correlation between the independent variables.

The normalized regression equation is as follows:

$$
\mathrm{CB}=0.463+0.158 \mathrm{SO}+0.351 \mathrm{FO}+0.214 \mathrm{~EB}
$$

From the analysis results, it is shown that the influence of the factors on the consumption behavior of eco-fashion products gradually decreases as follows: the fashion-oriented factor has $\beta=0.351$; Environmentally friendly behavioral factor $\beta=0.214$ and shopping orientation factor $\beta=0.158$.

Factors of fashion orientation and shopping orientation are selected on the theory of fashion acceptance (Sproles, 1979) which asserts that consumers are interested in fashion and will buy eco-fashion products. Consumers are more interested in dressing well and tend to buy more eco-fashion products. To achieve sales and profits in the market, designers and manufacturers should develop garments that satisfy the consumer expectations of their customers. Vietnamese consumers are willing and eager to consume eco-fashion products, but the cost to buy such products is higher than fashion products made of conventional materials. 


\section{Factors Affecting the Consumption of Eco-Fashion Products of Vietnamese Consumers}

To raise consumers' awareness of environmental issues, garment companies have taken care and produced eco-fashion products, enhancing their image and their social responsibility to the environment. school. As a result of the survey, 450 respondents said that environmental issues are increasingly concerned and more than $85 \%$ of them confirmed that they would buy eco-fashion products in the future. The problem of dyes and chemicals used in the production of clothing can harm the environment, affecting the quality of life of everyone in society.

\section{Management Implications}

The research results show that the factors that determine the consumer behavior of eco-fashion products in Vietnam include three factors, which are fashion trends, shopping orientation factors, and shopping orientation factors. Environmentally friendly behavioral factors

To promote the consumption behavior of eco-fashion products, the author proposes the following managerial implications: Firstly, businesses should focus on researching and producing dyes derived from nature, which do not pollute the environment. Second, businesses should focus on branding activities about eco-fashion, clarifying the positive impact of consuming eco-fashion products so that consumers can see their responsibility when choosing eco-fashion products to select consumable products.

Third, businesses that focus on research and development to improve products in terms of materials and processes need to focus on trendy designs. Besides, pay attention to customer segmentation to build an appropriate strategy.

\section{REFERENCES}

1) Hoang Thi Bao Thoa (2016). Green consumption trends in the world and implications for Vietnam. Scientific Journal of Vietnam National University, Hanoi: Economics and Business, 32(1), 66 - 72.

2) Neilson (2017). Commitments to sustainable development will influence the purchasing decisions of Vietnamese consumers. Extracted on 01/03/2018 at: http://www.nielsen.com/vn/en/insights/2017/nielsen-csr-2017.html

3) Nguyen Vu Hung, Nguyen Hung Cuong and Hoang Luong Vinh (2015). Green lifestyle and consumption from the perspective of the theory of planned behavior. Economy and Development, 216, 57 - 65.

4) Prime Minister (2012). Decision approving the National Green Growth Strategy - 1393/QD-TTg. Extracted on March 1, 2018 at: http://www.chinhphu.vn/portal/page/portal/chinhphu/noidungchienluoc phattrientinhtexahoi?_ piref135_ 16002_135_15999_15999.strutsAction=ViewDetailAction.do\&_piref135_16002_135_15999_1514999_pitract=15999_1 5999_docid.

5) Ajzen, I. (1991). The theory of planned behavior. Organizational Behavior and Human Decision Processes,50(2), 179 - 211.

6) Cervellon, M., \& Carey, L. (2011). Consumers perceptions of green: Why and how consumers use eco-fashion and green beauty products.Critical Studies in Fashion \& Beauty,2(1), 117 - 138.

7) Kotler, P., \& Keller, KL (2012).Marketing management. Prentice Hall, One Lake Street, Upper Saddle River, New Jersey.

8) Lorek, S., \& Fuchs, D. (2013). Strong sustainable consumption governance- precondition for a degrowth path?Journal of Cleaner Production,38, 36 - 43.

9) Ottman, JA (2011). The New Rules of Green Marketing: Strategies, Tools, and Inspiration for Sustainable Branding, Greenleaf Publishing, Aizlewoods Mill, Nursery Street, UK. 